\title{
SOSIALISASI RAGAM TEKNOLOGI RAMAH LINGKUNGAN DALAM PEMANFAATAN AMPAS TEH SEBAGAI UPAYA MENDUKUNG SUSTAINABLE FARMING DI DESA TUGUMUKTI
}

\author{
Fetty Dwi Rahmayanti \\ Universitas Borobudur, Jakarta Timur, DKI Jakarta, Indonesia \\ Email : fetty_dwi@borobudur.ac.id
}

Manuskrip: Desember -2021; Ditinjau: Januari -2022; Diterima: Januari -2022; Online: Januari-2022; Diterbitkan: Januari-2022

\begin{abstract}
ABSTRAK
Dalam mendukung penerapan program pemerintah mewujudkan pertanian berkelanjutan (sustainable farming), salah satu upaya yang dapat ditempuh yaitu dengan memanfaatkan kembali limbah hasil kegiatan pertanian. Limbah hasil kegiatan pertanian tersebut diolah dengan menggunakan teknologi yang sederhana hingga menggunakan teknologi modern sehingga akan menghasilkan suatu produk yang bernilai. Desa Tugumukti merupakan desa yang berada di Kecamatan Cisarua, Kabupaten Bandung Jawa Barat yang memiliki wilayah geografis berbukit dan memiliki perkebunan teh yang cukup luas. Banyaknya hasil kegiatan pertanian dari perkebunan teh yang berada di sekitar desa, khususnya sisa hasil pertanian berupa ampas teh, menjadi hal menarik yang perlu disosialisasikan dalam pemanfaatan teh tersebut. Pengabdian masyarakat ini dilakukan dengan metode penyuluhan. Metode ini digunakan sebagai bentuk sosialisasi yang memungkinkan sesuai dengan kondisi desa dalam memberikan informasi dan berdiskusi bersama masyarakat dalam mengetahui dan memahami apa itu ampas teh serta menjelaskan teknologi ramah lingkungan yang dapat digunakan dalam pemanfaatan ampas teh. Ampas teh yang merupakan limbah atau zat sisa dapat memberikan manfaat dan nilai tambah dengan melakukan daur ulang limbah teh. Ragam teknologi ramah lingkungan telah banyak dikembangkan saat ini dalam pemanfaatan ampas teh, diantaranya penerapan produksi bersih, pemanfaatan ampas teh sebagai adsorben dan pemanfaatan ampas teh sebagai media tanam jamur tiram putih. Ragam teknologi ramah lingkungan ini diharapkan dapat memberikan kontribusi sebagai salah satu wujud dari penerapan pertanian berkelanjutan (sustainable farming).
\end{abstract}

\section{Kata Kunci: Ampas Teh, Ramah Lingkungan, Sustainable Farming}

\section{PENDAHULUAN}

Dalam mendukung penerapan program pemerintah mewujudkan pertanian berkelanjutan (sustainable farming), salah satu upaya yang dapat ditempuh yaitu dengan memanfaatkan kembali limbah hasil kegiatan pertanian. Limbah hasil kegiatan pertanian tersebut diolah dengan menggunakan teknologi yang sederhana hingga menggunakan teknologi modern sehingga akan menghasilkan suatu produk 
yang bernilai.

Teh (Camellia sinensis) adalah salah satu tanaman perkebunan yang sangat diminati oleh masyarakat Indonesia sebagai salah satu minuman tradisional yang menyehatkan dan menyegarkan, bahkan saat ini aroma teh dan olahannya juga banyak dikembangkan sebagai cita rasa untuk berbagai macam makanan (roti dan kue). Saat ini teh yang laku dipasaran umumnya adalah teh hitam, teh hijau, teh oolong dan teh wangi.

Menurut Syakir (2010), tanaman teh berasal dari sub tropis maka cocok ditanam di daerah pegunungan dan merupakan tanaman tahunan yang saat ini bukan lagi sekedar minuman tetapi kini sudah dirasakan dapat meningkatkan kesadaran akan gaya hidup sehat di kota besar. Menurutnya moderenisasi teh menjadi gaya hidup merupakan revitalisasi budaya dalam hal ini tradisi minum teh yang telah melekat dikalangan anak-anak, remaja, dewasa hingga lansia. Banyaknya permintaan dan pemanfaatan teh untuk kebutuhan sehari-hari dan industri maka semakin meningkat juga ampas atau sisa teh yang dihasilkan.

Desa Tugumukti merupakan desa yang berada di Kecamatan Cisarua, Kabupaten Bandung Jawa Barat yang memiliki wilayah geografis berbukit dan memiliki perkebunan teh yang cukup luas. Sebagian besar mata pencaharian penduduknya adalah bertani. Mayoritas petani di Desa Tugumukti adalah petani teh yang bekerja pada orang maupun bekerja di kebun sendiri. Banyaknya hasil kegiatan pertanian dari perkebunan teh yang berada di sekitar desa, khususnya sisa hasil pertanian berupa ampas teh, menjadi hal menarik yang perlu disosialisasikan dalam pemanfaatan teh tersebut.

Berdasarkan uraian diatas, maka diperlukan sosialisasi kepada masyarakat Desa Tugumukti untuk mengetahui dan memahami bahwa ampas teh yang dihasilkan selama ini dapat memberikan manfaat dengan penambahan input teknologi ramah lingkungan guna mendukung sustainable farming.

\section{METODE PELAKSANAAN KEGIATAN}

Kegiatan pengabdian kepada masyarakat ini dilaksanakan selama satu hari tanggal 21 Agustus 2021 bertempat di Sentra Kelompok Tani Binaan Tani Pintar Indonesia Desa Tugumukti RT.01/RW.08, Kecamatan Cisarua, Kabupaten Bandung, Jawa Barat.

Pengabdian masyarakat ini dilakukan dengan metode penyuluhan. Metode ini digunakan sebagai bentuk sosialisasi yang memungkinkan sesuai dengan kondisi desa dalam memberikan informasi dan berdiskusi bersama masyarakat dalam mengetahui dan memahami apa itu ampas teh serta menjelaskan teknologi ramah lingkungan yang dapat digunakan dalam pemanfaatan ampas the.

\section{HASIL DAN PEMBAHASAN}

Masyarakat Desa Tugumukti mengikuti serangkaian kegiatan pengabdian masyarakat dengan antusias. Masyarakat yang ikut serta dalam kegiatan ini mayoritas adalah petani teh yang telah menekuni profesinya selama bertahun-tahun. Pada kegiatan ini juga dilakukan sharing knowledge dan diskusi tanya jawab dari 
pengalaman masyarakat selama ini dilapangan selama berkebun teh dan penanganan ampas teh yang telah dilakukan dan apa yang dianjurkan.

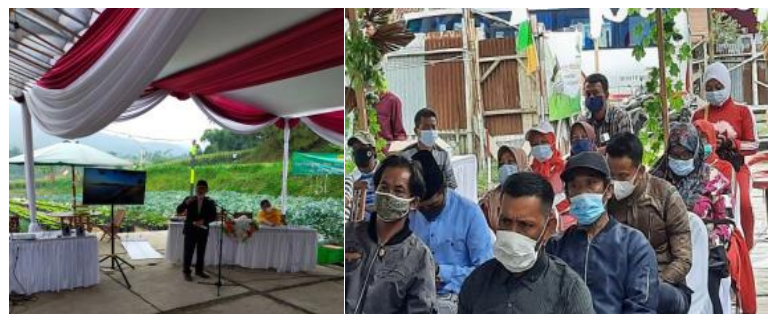

Gambar 1. Kegiatan Pengabdian Masyarakat di Desa Tugumukti, Jawa Barat

Ampas teh merupakan salah satu limbah pertanian yang tergolong limbah organik dan berpotensi untuk didaur ulang sehingga dapat dimanfaatkan untuk menghasilkan suatu produk. Pemanfaatan ampas teh umumnya dilakukan oleh rumah tangga, pelaku industri rumah tangga hingga industri berskala besar. Saat ini dalam mewujudkan pertanian berkelanjutan yang telah disosialisasikan pemerintah, ragam teknologi ramah lingkungan dalam pemanfaatan ampas teh telah banyak dilakukan masyarakat, diantaranya yaitu :

1. Penerapan Produksi Bersih (Cleaner Production), teknologi ramah lingkungan ini digunakan untuk mendukung produksi bersih di industri teh dengan melakukan pemanfaatan kembali limbah yang telah dihasilkan dari kegiatan industri teh. Menurut Balittri (2013), produksi bersih adalah strategi pengelolaan lingkungan yang sifatnya mengarah pada pencegahan terpadu yang diterapkan pada seluruh siklus produksi yeng bertujuan untuk meningkatkan produktivitas melalui efisiensi yang lebih baik pada penggunaan bahan mentah, energi dan air serta menjaga kualitas lingkungan melalui pengurangan sumber penghasil limbah atau emisi. Salah satu kegiatan yang dilakukan dalam mendukung produksi bersih di industri teh dengan melakukan pemanfaatan kembali limbah padat dan limbah cair yang dihasilkan. Limbah padat dapat diolah dan dimanfaatkan menjadi bahan baku pembuatan papan partikel dan pupuk organik. Menurut Balittri (2013), ampas teh yang akan dijadikan pupuk tanaman diproses melalui pengolahan secara termofil dan menambahkan mikroorganisme didalamnya (Gambar 2). Tujuan penambahan mikroorganisme tersebut yaitu untuk mempercepat proses penguraian. Selain itu limbah padat teh hitam berasarkan hasil penelitian bahwa dapat menurunkan produksi gas metan hasil fermentasi ternak sapi perah atau sapi potong, sehingga dapat meningkatkan produktivitas peternakan.

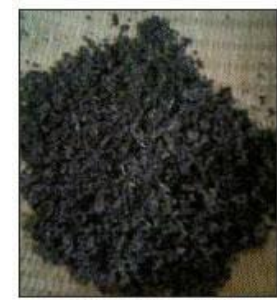

Gambar 2. Ampas Teh 
2. Pemanfaatan Ampas Teh sebagai Adsorben untuk menurunkan kadar besi (Fe) air. Ampas teh berdasarkan hasil penelitian mengandung senyawa flavonoid yang terbukti mampu menurunkan kadar besi $(\mathrm{Fe})$ yang mencemari air. Secara sederhana ampas teh dicuci, setelah dicuci dikeringkan dan dihaluskan. Menurut penelitian Anditya, et al (2018), air bersih dengan kualitas memenuhi persyaratan Permenkes (Peraturan Menteri Kesehatan) kadar Fe maksimal sebesar 1,0 mg/L, hasil penelitiannya setelah dilakukan adsorpsi menggunakan ampas teh ternyata mampu menurunkan kadar Fe air hingga mencapai titik jenuh dalam waktu 120 menit, yang awalnya kadar Fe air tesebut dari $2 \mathrm{mg} / \mathrm{L}$ namun setelah menggunakan adsorben ampas teh menjadi $0.3 \mathrm{mg} / \mathrm{L}$. Selanjutnya air yang dihasilkan dari proses adsorpsi ampas teh tersebut, dapat digunakan bagi kebutuhan sehari-hari termasuk untuk pengairan tanaman pertanian.

3. Pemanfaatan Ampas Teh sebagai media pertumbuhan Jamur Tiram Putih (Pleurotus ostreatus). Ampas teh juga dapat dimanfaatkan sebagai media untuk pertumbuhan jamur tiram putih karena ampas teh banyak mengandung mineral yang diyakini memiliki kandungan yang sama dengan media pertumbuhan jamur yang kita ketahui selama ini umumnya menggunakan serbuk gergaji. Hasil penelitian Saptari et al. (2016), limbah ampas teh dapat dijadikan media tanam yang efektif untuk jamur tiram putih (Pleurotus ostreatus) karena mengandung mineral karbon organik, tembaga $(\mathrm{Cu}) 20 \%$, Magnesium $(\mathrm{Mg}) 10 \%$ serta Kalsium (Ca) 13\% yang sangat cocok dijadikan media pertumbuhan jamur tiram putih dengan pertumbuhan miselium tercepat. Ampas teh yang dipergunakan diperoleh dari residu atau sisa teh yang sudah diseduh dalam pembuatan teh dan menjadi limbah rumah tangga. Saat ini petani jamur tiram putih sudah mulai memanfaatkan ampas teh sebagai media tanam karena khasiat yang dimiliki sama seperti serbuk gergaji bahkan mudah didapatkan dan relatif memerlukan biaya yang lebih sedikit, sehingga diharapkan dengan input yang lebih kecil akan mendapatkan output yang besar sehingga dapat meningkatkan produktivitas petani jamur tiram putih

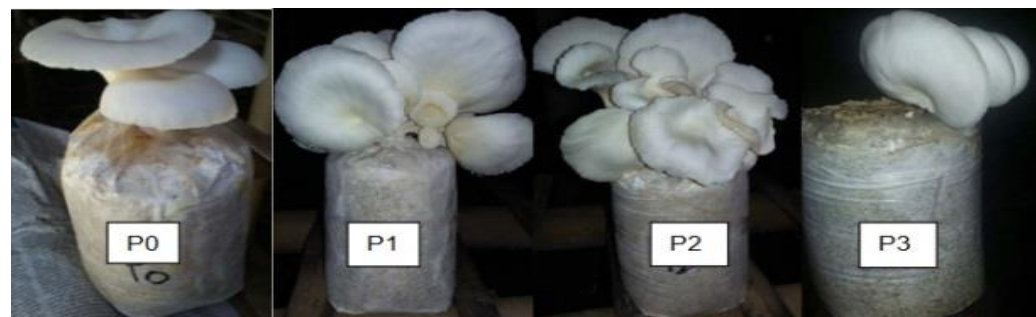

Gambar 3. Media Tanam Jamur Tiram Putih (Pleurotus ostreatus) Menggunakan Ampas Teh (Sumber : Saptari et al. (2016).

\section{KESIMPULAN}

Kegiatan pengabdian masyarakat ini tepat dilakukan kepada masyarakat Desa Tugumukti yang notabennya didominasi oleh masyarakat yang bermata pencaharian petani teh. Kegiatan ini diharapkan dapat membuka wawasan petani dalam pemanfaatan ampas teh. 
Ampas teh yang merupakan limbah atau zat sisa dapat memberikan manfaat dan nilai tambah dengan melakukan daur ulang limbah teh. Ragam teknologi ramah lingkungan telah banyak dikembangkan saat ini dalam pemanfaatan ampas teh, diantaranya penerapan produksi bersih, pemanfaatan ampas teh sebagai adsorben dan pemanfaatan ampas teh sebagai media tanam jamur tiram putih. Ragam teknologi ramah lingkungan ini diharapkan dapat memberikan kontribusi sebagai salah satu wujud dari penerapan pertanian berkelanjutan (sustainable farming).

\section{UCAPAN TERIMA KASIH}

Pada kesempatan ini penulis ucapkan terima kasih kepada Rektor Universitas Borobudur dan Kepala Desa Tugumukti, Kecamatan Cisarua, Kabupaten Bandung yang telah mendukung dalam kegiatan pengabdian masyarakat. Terima kasih juga kami sampaikan kepada Dekan Fakultas Pertanian Universitas Borobudur, dan rekan-rekan Dosen Fakultas Pertanian Universitas Borobudur juga masyarakat Desa Tugumukti dan mahasiswa yang turut serta dalam kegiatan pengabdian masyarakat. Kiranya hasil pengabdian masyarakat ini mudah-mudahan dapat bermanfaat sebagai salah satu luaran dari ilmu pengetahuan.

\section{DAFTAR PUSTAKA}

Anditya, Fauzan Hafids, Choirul Amri, Tuntas Bagyono. 2018. Pemanfaatan Ampas Teh (Camellia sinensis) Sebagai Adsorben Penurunan Kadar Fe Air Sumur Gali. Poltekkes Yogyakarta. http://www.litbang.kemkes.go.id:8080/handle/123456789/40386?show=full

Balittri (Balai Penelitian Tanaman Industri dan Penyegar). 2013. Beberapa Pemanfaatan Limbah Dari Industri Teh. Puslitbang Perkebunan, Badan Litbang Pertanian, Kementerian Pertanian. http://balittri.litbang.pertanian.go.id/index.php/berita/info-teknologi/183beberapa-pemanfaatan-limbah-dari-industri-teh. Diakses 29 Agustus 2021. Saptari, Tri Haryani, Ani Apriliyani, S.Y.Srie Rahayu. 2016. Pemanfaatan Limbah Ampas Teh Dan Kardus Sebagai Media Pertumbuhan Dan Produktivitas Jamur Tiram Putih (Pleurotus ostreatus). Program Studi Biologi, FMIPA, Universitas Pakuan Bogor. In: Seminar Nasional Tahunan Matematika, Sains, dan Teknologi 2016, 22 September 2016, Balai Sidang Universitas Terbuka (UTCC). http://repository.ut.ac.id/id/eprint/6386.

Syakir, M, Dedi Soleh, M.Yusron, Wiratno. 2010. Budidaya dan Pasca Panen Teh. Pusat Penelitian dan Pengembangan Perkebunan, Badan Penelitian dan Pengembangan Pertanian, Kementerian Pertanian. Bogor. 